Boise State University

ScholarWorks

Biology Faculty Publications and Presentations

Department of Biological Sciences

6-1-2001

\title{
High Species Diversity in Fleshy-Fruited Tropical Understory Plants
}

James F. Smith

Boise State University 


\section{High Species Diversity in Fleshy-Fruited Tropical Understory Plants}

James F. Smith ${ }^{*}$

Department of Biology, Boise State University, Boise, Idaho 83725

Submitted July 10, 2000; Accepted February 1, 2001

ABSTRACT: Key innovations may increase the number of taxa in a clade that possesses the proposed innovation in comparison to its sister group that lacks the trait through either increased speciation or reduced extinction rates. Comparing sister clades across several independent lineages provides statistical support that the trait has increased species diversity. Previous studies have indicated that there may not be a relationship between biotic dispersal and higher species diversity, but only a few of these studies specified habit, habitat, or type of disperser. No previous study has specified all of the above parameters and used a phylogenetic approach. This article examines species diversity in numerous lineages of tropical understory plants with small, fleshy, bird-dispersed fruits for which a reliable estimate of phylogenetic relationships is available. Clades with fleshy fruits are significantly more diverse than sister clades with dry fruits.

Keywords: diversity, dispersal, key innovation, fruits, frugivory, plants.

Within evolutionary biology, key innovations may be defined as characters that allow a clade to utilize new, previously unexploited ecological niches (Futuyma 1998). Key innovations may lead to increased diversity but need not do so. Several studies have used key innovations to explain greater species diversity in specific lineages. In these studies, lineages with the key innovation have been shown to have greater species diversity than lineages that lack the trait. Examples include the presence of nectar spurs in flowers of Aquilegia (Ranunculaceae) that allow the plants to utilize different forms of pollen vectors (Hodges 1997) and the adhesive capture threads of araneoid orb-web spiders that allow them to place their webs in vertical positions in open sunny areas yet remain invisible to prey (Bond and Opell 1998).

One means to test whether a key innovation leads to

\footnotetext{
* E-mail: jsmith14@email.boisestate.edu.
}

Am. Nat. 2001. Vol. 157, pp. 646-653. (C) 2001 by The University of Chicago. 0003-0147/2001/15706-0006\$03.00. All rights reserved. increased species diversity is to compare multiple instances in which the trait has evolved. If the trait has resulted in increased species diversity, then clades with the trait should be more diverse than clades lacking the trait. Older clades are more likely to have generated more species; therefore the clades to be compared must be equivalent in age (e.g., sister groups). Therefore, accurate phylogenetic assessments are critical in assessing specific characters and their effects on species diversity. Recent advancements in phylogenetic analysis have improved our understanding of evolutionary relationships for many groups, especially among plants. This improved phylogenetic assessment of plant relationships has allowed evolutionary biologists to examine many traits previously proposed as affecting species diversity in a new light.

Dispersal syndromes have been inferred to explain the high species diversity of angiosperms compared to nonfruiting plants (Regal 1977; Burger 1981; Tiffney 1984, 1986; Tiffney and Mazer 1995), with the general idea that animal dispersal of fruits and pollen has resulted in greater specialization and thus increased speciation. This view has been challenged by comparing species numbers in groups with biotic versus abiotic dispersal, which leads to the general conclusion that biotic dispersal of fruits is not in itself a statistically significant factor in explaining angiosperm diversity (Herrera 1989; Eriksson and Bremer 1991, 1992; Fleming 1991; Midgley and Bond 1991; Bremer and Eriksson 1992). Most authors conclude that a combination of traits, such as dispersal type and growth form (Eriksson and Bremer 1991; Tiffney and Mazer 1995) or dispersal type and specific ecological conditions (Herrera 1989; Eriksson and Bremer 1991; Bremer and Eriksson 1992), may explain species diversity in certain groups of plants.

If we restrict our focus to plants with specific growth forms and specific ecological conditions, a correlation between biotic fruit dispersal and higher species diversity seems to exist. For example, within the Neotropical herbaceous plant subfamily Gesnerioideae, the genera with fleshy fruits tend to be the most diverse. Columnea sensu lato, which has berry fruits, has over 300 species (Smith 1994; Burtt and Wiehler 1995). Besleria, also with berry 
fruits, has over 200 species (Burtt and Wiehler 1995). Drymonia (140 species) and Alloplectus (75 species), both with fleshy dehiscent fruits, rank third and fifth in species number in the Neotropics. The only genus with dry capsular fruits to have more species than Alloplectus is Nautilocalyx, with $\sim 80$ species (Burtt and Wiehler 1995). The coincident greater number of species and fleshy fruits suggests that fleshiness may have affected the rate of speciation or extinction in these taxa.

To further examine the relationship between fruit type and species diversity that seems apparent in Gesneriaceae, this article examines the impact of biotic versus abiotic fruit-dispersal syndromes in a specific ecological context across an array of taxa. If the mode of dispersal is to have an impact on species diversification of the plants, then it is imperative to focus on plants that have similar disperser groups. Similar dispersers are more likely to exhibit similar behaviors that may result in similar patterns of speciation (Snow 1981). Herein, biotic dispersal is limited to fleshy fruits and only to plants in tropical forest understory habitats. This mostly limits dispersal agents to tropical understory birds (bats are included in at least one comparison) that have similar patterns of movement (Diamond 1973; Greenberg 1981; Snow 1981). Because of the habitat restriction, there is also an underlying restriction on growth form; thus, only herbs, shrubs, and small trees are included. This is the first study to examine effects of biotic versus abiotic dispersal on diversity in a phylogenetic context that specifies habit, habitat, and disperser.

\section{Methods}

In order to minimize the group of confounding variables, several criteria were used in selecting taxa to test the hypothesis that small fleshy fruits have higher species diversity in tropical understory plants. First, the sister group to a fleshy-fruited clade consisted of dry-fruited species. Second, it was essential to establish which types of fleshy fruits were to be included. Plants produce a wide array of fleshy fruits that correspond to different means of dispersal and vary in their size, thickness of exocarp, and number of seeds. In this article fleshy fruits have been restricted to small fleshy fruits that correspond to a bird-dispersal syndrome. In one case (Piperaceae), this probably also included bat dispersal since fruits of Piper are dispersed by both bats (Heithaus and Fleming 1978; Fleming and Heithaus 1981) and birds (Snow 1981). Because behavior patterns in terms of movement for tropical understory birds and bats are similar (Heithaus and Fleming 1978; Morrison 1978; Fleming and Heithaus 1981), the inclusion of bat-dispersed fruits is unlikely to affect the conclusions of this analysis. The definition of fleshy fruit used here includes fruits that are sufficiently small in size that they could be consumed whole by most understory birds. Larger drupes were excluded from the analysis, as were fruits that technically fit the definition of berry but were large and would therefore have dispersal mechanisms other than frugivorous birds (e.g., Passifloraceae). Third, only taxa (both fleshy and dry fruited) that were understory plants were used. Since the focus is on dispersal units and their dispersers, it is essential that a restricted habitat with its own particular group of dispersers be examined. In most cases these plants were herbaceous, but small trees and shrubs, such as Rubiaceae, also were included. Taxa that were composed entirely of canopy trees were not included. Fourth, the taxa (both fleshy and dry fruited) had either an entirely or primarily tropical distribution. In many cases, a few species or even genera are known from temperate regions, but the vast majority of species have a tropical distribution. The only exception to this was within Onagraceae. The genus Fuchsia has a distribution almost entirely composed of tropical understory shrubs or herbs. However, its sister genus, Circaea, as well as most other members of the family, has an exclusively temperate distribution. Analyses were done with and without Onagraceae to determine whether this biased the analysis. Finally, the taxa must have a well-supported phylogenetic estimate of relationships. This last criterion was critical in determining sister group relationships to the fleshy-fruited clade. In one case different gene trees or different analyses have shown alternative sister groups (Viscaceae; Chase et al. 1993; Nickrent and Soltis 1995; Nickrent et al. 1998). In this case, the alternatives also were tested. Similarly, the sister to the Columnea alliance of the Gesneriaceae comprised a clade of two dry-fruited genera (Nautilocalyx and Chrysothemis) and three fleshy-fruited genera (Nematanthus, Codonanthe, and Codonanthopsis; Smith 2000b). Because of the possible error in including fleshy-fruited taxa as part of the dry-fruited sister clade, two different comparisons were made, one with the fleshy-fruited species included and one without. Although the presence of fleshy fruits in the sister clade to the Columnea alliance implies that the fleshy state is ancestral, a full phylogenetic analysis of tribe Episcieae, to which these genera belong, clearly shows that dry fruits are ancestral to the tribe and the Columnea alliance and its sister group (Smith 2000b).

Sister group comparisons are listed in table 1 with the references for the source of the cladogram. The source for numbers of species per clade was Mabberly (1987), although more accurate estimates were obtained from the literature for Gesneriaceae (Burtt and Wiehler 1995), Bromeliaceae (Smith and Downs 1974, 1977, 1979), and Solanaceae (D'Arcy 1991). Numbers of species in each of the sister clade comparisons are listed in table 2. 
Table 1: Clades used in this study and the source of the cladogram used in the analysis

\begin{tabular}{|c|c|c|c|}
\hline Family & Clade & Taxon & Cladogram source \\
\hline Gesneriaceae & $\begin{array}{l}\text { Besleria-Gasteranthus-Cremospermal Reldia- } \\
\text { Resia-Anetanthus-Tylopsacas }\end{array}$ & Genus & Smith $2000 a$ \\
\hline Gesneriaceae & Columnea alliance/Nautilocalyx-Chrysothemis & Genus & $\begin{array}{l}\text { Smith and Carroll 1997; Smith } \\
2000 b\end{array}$ \\
\hline Gesneriaceae & $\begin{array}{l}\text { Columnea alliance/Nautilocalyx-Chrysothemis- } \\
\text { Nematanthus-Codonanthe-Codonanthopsis }\end{array}$ & Genus & $\begin{array}{l}\text { Smith and Carroll 1997; Smith } \\
2000 b\end{array}$ \\
\hline Gesneriaceae & $\begin{array}{l}\text { Nematanthus-Codonanthe-Codonanthopsisl } \\
\text { Nautilocalyx-Chrysothemis }\end{array}$ & Genus & $\begin{array}{l}\text { Smith and Carroll 1997; Smith } \\
\quad 2000 b\end{array}$ \\
\hline Gesneriaceae & RufodorsialAlsobia-Cobonanthus & Genus & $\begin{array}{l}\text { Smith and Carroll 1997; Smith } \\
2000 b\end{array}$ \\
\hline Onagraceae & Fuchsia/Circaea & Genus & $\begin{array}{l}\text { Conti et al. 1993; Hoch and } \\
\text { Raven } 1995\end{array}$ \\
\hline \multicolumn{4}{|l|}{ Araceae/Najadaceae- } \\
\hline Alismataceae & & Family & Duvall et al. 1993; Davis 1995 \\
\hline Piperaceae & $\begin{array}{l}\text { Piper-Peperomia-Pothomorphe-Macropiper- } \\
\text { Zippelia/Anemopsis-Houttuynia- } \\
\text { Gymnotheca-Saururus }\end{array}$ & Genus & Tucker et al. 1993 \\
\hline Bromeliaceae & Bromelioideae/Puya & Subfamily/genus & Terry et al. 1997 \\
\hline Solanaceae & Solanoideae/Anthercidae-Nicotiana & Subfamily/genus & $\begin{array}{l}\text { Olmstead and Palmer 1992; } \\
\text { Olmstead and Sweere } 1994\end{array}$ \\
\hline \multicolumn{4}{|l|}{ Viscaceae/Eremolepataceae- } \\
\hline Santalaceae & & Family & Nickrent and Soltis 1995 \\
\hline Viscaceae/Eremolepataceae & & Family & Nickrent and Soltis 1995 \\
\hline Viscaceae/Santalaceae & & Family & Nickrent et al. 1998 \\
\hline Viscaceae/Olacaceae & & Family & Chase et al. 1993 \\
\hline Strychnaceae & & Family & Struwe et al. 1994 \\
\hline Rubiaceae & Coccocypselum/Hindsia-Declieuxia & Genus & $\begin{array}{l}\text { Bremer and Eriksson 1992; } \\
\text { Andersson and Rova } 1999\end{array}$ \\
\hline Rubiaceae & Catesbaea/Cubanola & Genus & $\begin{array}{l}\text { Bremer et al. 1995; Andersson } \\
\text { and Rova } 1999\end{array}$ \\
\hline Vitaceae/Dilleniaceae & & Family & Chase et al. 1993 \\
\hline
\end{tabular}

Note: A slash (/) is used to separate sister groups, with the fleshy-fruited clade before the slash. Hyphens (-) are used to indicate members of the same clade.

To test whether the fleshy-fruited clade contained more species than its dry-fruited sister clade, the test of Slowinski and Guyer (1993) was used. This test has been important in numerous other attempts to compare species richness between clades (Hodges 1997; Bond and Opell 1998; Dodd et al. 1999). This test takes into account the number of species in each of the clades and is not simply a test of whether one group is larger than the other. This test also has greater statistical power than nonparametric tests (Sanderson and Donoghue 1996). Each sister group pair is examined to calculate a natural log proportion of species in the sister group lacking the proposed key innovation $\left(-\ln p_{i}\right)$. These are summed for all pairs and compared to a $\chi^{2}$ distribution. The test statistic was calculated with and without Onagraceae, with alternatives as sister group to the Columnea alliance (table 2), with alternatives as sister group to Viscaceae (table 2), and all possible combinations of the above. The test of Sanderson and Don- oghue (1994) requires more information than is currently available (times of divergence, greater structure within clades) or extensive computational time to test ranges of divergence time for all groups.

\section{Results and Discussion}

In only three of the 14 comparisons was the fleshy-fruited clade smaller than its sister group (table 2). Of these three, one has alternative phylogenetic hypotheses that would make it the larger of the two clades. In all cases, regardless of the sister clade to Viscaceae, the sister to the Columnea alliance, or whether the Onagraceae were included, the fleshy-fruited clade has significantly more species than its dry-fruited sister clade (table 3 ). These results indicate that fleshy-fruited clades are generally larger than their dryfruited sister clades in tropical understory plants. 
Table 2: Number of genera in fleshy-fruited/non-fleshy-fruited clades, $p_{i}$, and $-\ln p_{i}$

\begin{tabular}{|c|c|c|c|}
\hline Taxa (fleshy/nonfleshy) & $\begin{array}{l}\text { Number of species } \\
\text { in each clade }\end{array}$ & $p_{i}^{\mathrm{a}}$ & $-\ln p_{i}$ \\
\hline \multicolumn{4}{|l|}{ Besleria, Gasteranthus, Cremosperma/Reldia, Resia, } \\
\hline Anetanthus, Tylopsacas & $265 / 10$ & .036 & 3.3105 \\
\hline \multicolumn{4}{|l|}{ Columnea alliance/Nautilocalyx, Chrysothemis, } \\
\hline Nematanthus, Codonanthe, Codonanthopsis & $535 / 142$ & .210 & $1.5604^{\mathrm{b}}$ \\
\hline Columnea alliance/Nautilocalyx, Chrysothemis & $535 / 87$ & .140 & $1.9654^{\mathrm{b}}$ \\
\hline RufodorsialAlsobia, Cobonanthus & $4 / 3$ & .500 & .6931 \\
\hline \multicolumn{4}{|l|}{ Nematanthus, Codonanthe, Codonanthopsis/ } \\
\hline Nautilocalyx, Chrysothemis & $55 / 87$ & .617 & .4829 \\
\hline Fuchsia/Circaea & $100 / 7$ & .066 & $2.7175^{\mathrm{c}}$ \\
\hline Araceae/Najadaceae, Alismataceae & $2,950 / 130$ & .042 & 3.1648 \\
\hline \multicolumn{4}{|l|}{ Piper, Peperomia, Pothomorphe, Macropiper, } \\
\hline Zippelia/remainder of family & $2,020 / 6$ & .003 & 5.8216 \\
\hline Bromelioideae/Puya & $560 / 168$ & .231 & 1.4700 \\
\hline Solanoideae/Anthercidae, Nicotiana & $1,968 / 239$ & .108 & 2.2229 \\
\hline Viscaceae/Eremolepataceae, Santalaceae & $450 / 22$ & .047 & $3.0638^{\mathrm{b}}$ \\
\hline Viscaceae/Eremolepataceae & $450 / 13$ & .028 & $3.5706^{\mathrm{b}}$ \\
\hline Viscaceae/Santalaceae & $450 / 9$ & .197 & $3.9296^{\mathrm{b}}$ \\
\hline Viscaceae/Olacaceae & $450 / 900$ & .667 & $.4047^{\mathrm{b}}$ \\
\hline Strychnaceae & $217 / 58$ & .212 & 1.5527 \\
\hline Coccocypselum/Hindsia/Declieuxia & $20 / 35$ & .648 & .4336 \\
\hline Catesbaea/Cubanola & $10 / 2$ & .182 & 1.7047 \\
\hline Vitaceae/Dilleniaceae & $800 / 300$ & .273 & 1.2984 \\
\hline
\end{tabular}

The implication that fleshy-fruited clades are more diverse than dry-fruited clades differs from earlier studies that concluded there is no significant positive relationship between biotic fruit dispersal and diversity (Herrera 1989; Fleming 1991; Midgley and Bond 1991). In previous studies of dispersal and diversity, no distinction was made regarding ecological conditions (Fleming 1991; Midgley and Bond 1991), although Herrera (1989) suggested that fruit types may affect species diversity in specific ecological contexts. Because the ecological and climatic conditions along with growth form and disperser type were all specified in this study, a relationship between fruit type and diversity was discovered. In addition, this study utilized recently derived phylogenetic relationships such that sister group comparisons could be made.

Other studies have used phylogenetic estimates to examine diversity and fruit type but have come to conclusions different from those found here. Eriksson and Bremer (1991) and Bremer and Eriksson (1992) found that fleshy-fruited members of the family Rubiaceae were only more diverse than other taxa if they also were shrubs. Herbaceous plants were more diverse if they were abiotically dispersed. Although Eriksson and Bremer (1991) and Bremer and Eriksson (1992) are the closest in methodology to the approach taken in this investigation, there are still some differences that may account for the different results between the two studies. First, although Eriksson and Bremer (1991) utilized a phylogeny for the Rubiaceae, not all of the taxa used in their diversity analysis were included in the tree. Taxa that were not included in the phylogenetic analysis were added to the tree based on previous, nonphylogenetic classifications (Eriksson and Bremer 1991); therefore their estimates of diversity for each clade may be inaccurate. Alternatively, since they only sampled one family, it is possible that other characteristics of Rubiaceae, not examined as part of the investigation, may limit species diversity of biotically dispersed herbaceous plants. Eriksson and Bremer (1991) pointed out that because the tropical, herbaceous members of Rubiaceae inhabit highly specialized niches, it may be that habitat availability and not dispersal ability has prevented increased diversity within this group.

Tiffney and Mazer (1995) concluded that biotic fruit dispersal is a contributing factor to woody plant diversity but found no such relationship for herbaceous plants. On the contrary, they found that herbaceous plant families were more diverse if they were abiotically dispersed, in agreement with the results of Eriksson and Bremer (1991) 
Table 3: Results of the Slowinski and Guyer (1993) test of fleshy-fruited clades having a greater number of species than their non-fleshy-fruited sister clade

\begin{tabular}{lcccc}
\hline & $-2 \ln \Sigma p_{i}$ with & \multicolumn{3}{c}{$-2 \ln \Sigma p_{i}$ without } \\
Comparison & Fuchsia & $\chi^{2}$ & Fuchsia & $\chi^{2}$ \\
\hline la & 58.9940 & $<.005$ & 53.5590 & $<.005$ \\
lb & 59.8040 & $<.005$ & 54.3690 & $<.005$ \\
2a & 60.0076 & $<.005$ & 54.5726 & $<.005$ \\
2b & 60.8176 & $<.005$ & 55.3826 & $<.005$ \\
3a & 60.7256 & $<.005$ & 55.2906 & $<.005$ \\
3b & 61.5356 & $<.005$ & 56.1006 & $<.005$ \\
$4 \mathrm{a}$ & 53.6758 & $<.005$ & 48.2408 & $.010-.005$ \\
4b & 54.4858 & $<.005$ & 49.0508 & $.010-.005$ \\
\hline
\end{tabular}

Note: Values that included Fuchsia/Circaea are based on 15 comparisons ( $30 \mathrm{df}$ ), values without Fuchsia/Circaea are based on 14 comparisons ( $28 \mathrm{df}$ ). Numbers correspond to the different comparisons of Viscaceae and its sister clade, and letters correspond to the different sister groups to the Columnea alliance as listed in table 2.

for Rubiaceae. Tiffney and Mazer's (1995) results are based on family-level comparisons and are not viewed in a phylogenetic context. In addition, they combined endo- and ectozoochory (dispersal by attachment to the outside of the animal) as biotic dispersal (Tiffney and Mazer 1995). The combination of different dispersal types, lack of phylogenetic context, and analysis only at the family level may have obscured relationships between diversity and fruit type in tropical herbaceous plants as was found in the present study.

\section{Evolutionary Consequences of Fleshy Fruits}

To demonstrate that a key innovation has affected species diversity, it must be shown that the trait provides a means of affecting rates of speciation or extinction (Cracraft 1990; Skelton 1993; Heard and Hauser 1995; Hodges 1997; Bond and Opell 1998). Once a trait has been identified in a lineage with high species diversity, specific hypotheses can be generated to test whether the trait has an effect on either speciation or extinction.

Most plants with fleshy fruits are dispersed by frugivorous passerine birds. Many of these birds have limited dispersal abilities and will not cross water barriers such as rivers (Diamond 1973; Yumoto 1999). However, occasional long-distance dispersal events may result in colonization of a disjunct population (Snow 1981). Thus, fleshy fruits may limit dispersal and subsequent gene flow (Eriksson and Bremer 1991; Givnish 1996, 1997), which results in small populations isolated from each other and leads to classic models of allopatric speciation (Mayr 1963). In contrast, dispersal of dry fruits is generally not limited by animal behavior. Thus, abiotic dispersal may be restricted only by the ability of the seed to germinate and survive.

Limited dispersal alone may not be adequate to explain the high number of species for plants with fleshy fruits. With limited dispersal alone one would expect fleshyfruited taxa to have few species, each of which would have a narrow range. However, the majority of short-range dispersal events by resident birds is likely to be augmented by chance long-distance dispersal events from migrants (Greenberg 1981; Blake and Loiselle 1992).

\section{Summary}

Clearly, further work needs to be conducted on the evolutionary consequences of fleshy fruits on species diversity in tropical understory plants. The evidence presented here provides support for the hypothesis of an increased species diversity due to the presence of fleshy fruits and provides an indication that the increased diversity may be the result of limited seed dispersal with occasional long-distance dispersal resulting in isolation and allopatric speciation. Further studies are necessary to test the genetic variability within species of fleshy-fruited understory plants. If the hypothesis of limited dispersal ability is correct, one would expect to see populations with limited degrees of genetic variation within each population but that are distinctive from other such populations (Williams and Guries 1994). Williams and Guries (1994) demonstrated that three different plant species with differing degrees of dispersal (all were dispersed via attachment to the exterior of animals or gravity) had corresponding degrees of genetic structure among populations. Species with the lowest ability to disperse (gravity) had the greatest structure among popula- 
tions (due to limited gene flow between populations). Likewise, Hamilton (1999) has evidence that all individuals in a tropical forest fragment as large as 10 ha may have been established by a single dispersal event. Similar studies of this nature are needed for plants with fleshy fruits in tropical understory habitats. Studies of this nature will provide the necessary data toward resolving the impact of fleshy fruits on rates of speciation in tropical understory plants.

\section{Acknowledgments} ments on an earlier draft of this manuscript, M. Nepokroeff for sharing her data on Pacific Rubiaceae phylogeny, and T. J. Givnish for his comments on bird dispersal. Funding for this project was provided by a Faculty Research Associates release time grant from Boise State University.
I would like to thank C. F. Williams for his helpful com-

quence data. Annals of the Missouri Botanical Garden 80:672-685.

Cracraft, J. 1990. The origin of evolutionary novelties: pattern and process at different hierarchical levels. Pages 21-44 in M. Nitecki, ed. Evolutionary innovation. University of Chicago Press, Chicago.

D'Arcy, W. G. 1991. The Solanaceae since 1976, with a review of its biogeography. Pages 75-137 in J. G. Hawkes, R. N. Lester, M. Nee, and N. Estrada, eds. Solanaceae III: taxonomy, chemistry, evolution. Whitstable Litho, Whitstable, Kent.

$\rightarrow$ Davis, J. I. 1995. A phylogenetic structure of the monocotyledons, as inferred from chloroplast DNA restriction site variation, and a comparison of measures of clade support. Systematic Botany 20:503-527.

Diamond, J. M. 1973. Distributional ecology of New Guinea birds. Science (Washington, D.C.) 179:759-769.

$\rightarrow$ Dodd, M. E., J. Silvertown, and M. W. Chase. 1999. Phylogenetic analysis of trait evolution and species diversity variation among angiosperm families. Evolution 53: 732-744.

$\rightarrow$ Duvall, M. R., M. T. Clegg, M. W. Chase, W. D. Clark, W. J. Kress, H. G. Hills, L. E. Eguiarte, et al. 1993. Phy-

\section{Literature Cited}

$\rightarrow$ Andersson, L., and J. H. E. Rova. 1999. The rps16 intron and the phylogeny of the Rubioideae (Rubiaceae). Plan $\rightarrow$ Systematics and Evolution 214:161-186.

$\rightarrow$ Blake, J. G., and B. A. Loiselle. 1992. Fruits in the diets of Neotropical migrant birds in Costa Rica. Biotropic: $\rightarrow$ 24:200-210.

$\rightarrow$ Bond, J. E., and B. D. Opell. 1998. Testing adaptive radiation and key innovation hypotheses in spiders. Evolution 52:403-414.

$\rightarrow$ Bremer, B., and O. Eriksson. 1992. Evolution of fruit characters and dispersal modes in the tropical family $\mathrm{Ru}-$ biaceae. Biological Journal of the Linnean Society 47: 79-95.

$\rightarrow$ Bremer, B., K. Andreasen, and D. Olsson. 1995. Subfamilial and tribal relationships in the Rubiaceae based on $r b c \mathrm{~L}$ sequence data. Annals of the Missouri Botanical Garden 82:383-397.

$\rightarrow$ Burger, W. C. 1981. Why are there so many kinds of flowering plants? BioScience 31:572-581.

Burtt, B. L., and H. Wiehler. 1995. Classification of the family Gesneriaceae. Gesneriana 1:1-4.

$\rightarrow$ Chase, M. W., D. E. Soltis, R. G. Olmstead, D. Morgan, D. H. Les, B. D. Mishler, M. R. Duvall, et al. 1993. Phylogenetics of seed plants: an analysis of nucleotide sequences from the plastid gene $r b c \mathrm{~L}$. Annals of the Missouri Botanical Garden 80:528-580.

$\rightarrow$ Conti, E., A. Fischbach, and K. J. Sytsma. 1993. Triba $\rightarrow$ G relationships in Onagraceae: implications from $r b c \mathrm{~L}$ selogenetic hypotheses for the monocotyledons constructed from $r b c \mathrm{~L}$ sequence data. Annals of the Missouri Botanical Garden 80:607-619.

Eriksson, O., and B. Bremer. 1991. Fruit characteristics, life forms, and species richness in the plant family $\mathrm{Ru}-$ biaceae. American Naturalist 138:751-761.

. 1992. Pollination systems, dispersal modes, life forms, and diversification rates in angiosperm families. Evolution 46:258-266.

Fleming, T. H. 1991. Fruiting plant-frugivore mutualism: the evolutionary theater and the ecological play. Pages 119-144 in P. W. Price, T. M. Lewinshon, G. W. Fernandes, and W. W. Benson, eds. Plant-animal interactions: evolutionary ecology in tropical and temperate regions. Wiley, New York.

Fleming, T. H., and E. R. Heithaus. 1981. Frugivorous bats, seed shadows, and the structure of tropical forests. Biotropica 13(suppl.):45-53.

Futuyma, D. J. 1998. Evolutionary biology. Sinauer, Sunderland, Mass.

Givnish, T. J. 1996. Adaptive plant evolution on islands: classical patterns, molecular data, new insights. Pages 281-304 in P. R. Grant, ed. Evolution on islands. Oxford

- 1997. Adaptive radiation and molecular systematics: issues and approaches. Pages 1-54 in T. J. Givnish and K. J. Sytsma, eds. Molecular evolution and adaptive radiation. Cambridge University Press, New York.

Greenberg, R. 1981. Frugivory in some migrant tropical forest wood warblers. Biotropica 13:215-223. University Press, New York. 
$\rightarrow$ Hamilton, M. B. 1999. Tropical tree gene flow and seed dispersal. Nature (London) 401:129-130.

$\rightarrow$ Heard, S. B., and D. L. Hauser. 1995. Key evolutionar $\rightarrow$ innovations and their ecological mechanisms. History of Biology 10:151-173.

$\rightarrow$ Heithaus, E. R., and T. H. Fleming. 1978. Foraging movements of a frugivorous bat Carollia perspicillata (Phyllostomatidae). Ecological Monographs 48:127-143.

$\rightarrow$ Herrera, C. M. 1989. Seed dispersal by animals: a role in angiosperm diversification? American Naturalist $133 \rightarrow$ 309-322.

Hoch, P. C., and P. H. Raven. 1995. Introduction: perspectives in biosystematics. Pages xi-xxii in P. C. Hoch and A. G. Stephenson, eds. Experimental and molecula $\rightarrow$ approaches to plant biosystematics. Monographs in Systematic Botany from the Missouri Botanical Garden 53. Missouri Botanical Garden, St. Louis.

Hodges, S. A. 1997. Rapid radiation due to a key innovation in columbines. Pages 391-406 in T. J. Givnish and K. J. Sytsma, eds. Molecular evolution and adaptive radiation. Cambridge University Press, New York.

Mabberly, D. J. 1987. The plant book. Cambridge University Press, New York.

Mayr, E. 1963. Animal species and evolution. Harvard University Press, Cambridge, Mass.

$\rightarrow$ Midgley, J. J., and W. J. Bond. 1991. How important is biotic pollination and dispersal to the success of the angiosperms? Philosophical Transactions of the Royal Society of London B, Biological Sciences 333:209-215.

$\rightarrow$ Morrison, D. W. 1978. Foraging ecology and energetics of the frugivorous bat Artibeus jamaicensis. Ecology 59: 716-723.

$\rightarrow$ Nickrent, D. L., and D. E. Soltis. 1995. A comparison of angiosperm phylogenies from nuclear $18 \mathrm{~S}$ rDNA and $r b c \mathrm{~L}$ sequences. Annals of the Missouri Botanical Gar $\rightarrow$ den 82:208-234.

Nickrent, D. L., R. J. Duff, A. E. Colwell, A. D. Wolfe, N $\rightarrow$ D. Young, K. E. Steiner, and C. W. dePamphilis. 1998. Molecular phylogenetic and evolutionary studies of parasitic plants. Pages 211-241 in D. E. Soltis, P. S. Soltis, $\rightarrow$ and J. J. Doyle, eds. Molecular systematics of plants II: DNA Sequencing. Kluwer Academic, Boston.

$\rightarrow$ Olmstead, R. G., and J. D. Palmer. 1992. A chloroplast DNA phylogeny of the Solanaceae: subfamilial relation ships and character evolution. Annals of the Missouri Botanical Garden 79:346-360.

$\rightarrow$ Olmstead, R. G., and J. A. Sweere. 1994. Combining dat: $\rightarrow$ in phylogenetic systematics: an empirical approach using three molecular data sets in the Solanaceae. Systematic Biology 43:467-481.

Regal, P. J. 1977. Ecology and evolution of flowering plant dominance. Science (Washington, D.C.) 196:622-629.

Sanderson, M. J., and M. J. Donoghue. 1994. Shifts ir $\rightarrow$ Tucker, S. C., A. W. Douglas, and L. Han-Xing. 1993. diversification rate with the origin of the angiosperms. Science (Washington, D.C.) 264:1590-1593.

. 1996. Reconstruction shifts in diversification rates on phylogenetic trees. Trends in Ecology \& Evolution 11:15-20.

Skelton, P. W. 1993. Adaptive radiation: definition and diagnostic tests. Pages $45-58$ in D. R. Lees and D. Edwards, eds. Evolutionary patterns and processes. Academic Press, London.

Slowinski, J. B., and C. Guyer. 1993. Testing whether certain traits have caused amplified diversification: an improved method based on a model of random speciation and extinction. American Naturalist 142:1019-1024.

Smith, J. F. 1994. Systematics of Columnea section Pentadenia and section Stygnanthe (Gesneriaceae). Systematic Botany Monographs 44:1-89.

$\rightarrow-2000 a$. A phylogenetic analysis of tribes Beslerieae and Napeantheae (Gesneriaceae) and evolution of fruit types: parsimony and maximum likelihood analyses of $n d h \mathrm{~F}$ sequences. Systematic Botany 25:72-81.

$\rightarrow-2000 b$. Phylogenetic resolution within the tribe Episcieae (Gesneriaceae): congruence of ITS and $n d h \mathrm{~F}$ sequences from parsimony and maximum-likelihood analyses. American Journal of Botany 87:883-897.

$\rightarrow$ Smith, J. F., and C. L. Carroll. 1997. Phylogenetic relationships of the Episcieae (Gesneriaceae) based on $n d h \mathrm{~F}$ sequences. Systematic Botany 22:713-724.

Smith, L. B., and R. J. Downs. 1974. Pitcairnioideae. Published for Organization for Flora Neotropica, monograph 14. Hafner, New York.

- 1977. Tillandsioideae. Published for Organization for Flora Neotropica, monograph 14. Hafner, New York.

- 1979. Bromeilioideae. Published for Organization for Flora Neotropica, monograph 14. Hafner, New York. Snow, D. W. 1981. Tropical frugivorous birds and their food plants: a world survey. Biotropica 13:1-14. and family level classification of the Gentianales. Cladistics 10:175-206.

Terry, R. G., G. K. Brown, and R. G. Olmstead. 1997. Examination of subfamilial phylogeny in Bromeliaceae using comparative sequencing of the plastid locus $n d h \mathrm{~F}$. American Journal of Botany 84:664-670.

Tiffney, B. H. 1984. Seed size, dispersal syndromes, and the rise of the angiosperms: evidence and hypothesis. Annals of the Missouri Botanical Garden 71:551-576.

$\rightarrow$ 1986. Fruit and seed dispersal and the evolution of the Hamamelidae. Annals of the Missouri Botanical Garden 73:394-416.

$\rightarrow$ Tiffney, B. H., and S. J. Mazer. 1995. Angiosperm growth habit, dispersal and diversification reconsidered. Evolutionary Ecology 9:93-117.
Struwe, L., V. A. Albert, and B. Bremer. 1994. Cladistics 
Utility of ontogenetic and conventional characters ir $\rightarrow$ Yumoto, T. 1999. Seed dispersal by Salvin's curassow, Mitu determining phylogenetic relationships of Saururaceae and Piperaceae (Piperales). Systematic Botany 18: 614-641.

$\rightarrow$ Williams, C. F., and R. P. Guries. 1994. Genetic consequences of seed dispersal in three sympatric forest herbs. I. Hierarchical population-genetic structure. Evolution 48:791-805. salvini (Cracidae), in a tropical forest of Colombia: direct measurements of dispersal distance. Biotropica 31: 654-660. 